\title{
PEMBERDAYAAN MASYARAKAT BERBASIS TAUHID
}

\section{COMMUNITY EMPOWERMENTD BASED ON TAWHEE}

\author{
A Mahrudin'1, R Yektyastuti², dan Nurmalasari1a \\ 1Program Studi Manajemen Pendidikan Islam, Fakultas Keguruan dan Ilmu Pendidikan, \\ Universitas Djuanda Bogor, Jl. Tol Ciawi No.1 Kotak Pos 35 Bogor 16720 \\ 2Program Studi Pendidikan Guru Sekolah Dasar, Fakultas Keguruan dan Ilmu Pendidikan, \\ Universitas Djuanda Bogor, Jl. Tol Ciawi No.1 Kotak Pos 35 Bogor 16720 \\ a Koresponsdensi: Nurmalasari, Email: nurmalasari@unida.ac.id \\ (Diterima: 06-12-2016; Ditelaah: 07-12-2016; Disetujui: 04-02-2017)
}

\begin{abstract}
Community Service is learning process for student developed through community service activities in providing experience science, technology, art and religion, conducted within approximately 40 days. Community service can improve the ability of students in interacting with the real world outside the campus that is able to deal directly with the community. Student as an Agent Of Change can also develop their knowledge and insight in facing various problems that exist in Sukagalih Village community to do sustainable development that is needed in improving role and empowerment of society with aim to educate and realize prosperity of society of Sukagalih Village which is suitable with tauhid environment through various fields such as education, field of religion, health \& environment, creative economy, and social field.
\end{abstract}

Keyword: Community Service.

\begin{abstract}
ABSTRAK
Pengabdian masyarakat merupakan proses pembelajaran bagi mahasiswa yang dikembangkan melalui kegiatan pengabdian kepada masyarakat dalam memberikan pengalaman ilmu, teknologi, seni dan agama yang dilakukan dalam waktu kurang lebih 40 hari. Pengabdian masyarakat dapat meningkatkan kemampuan mahasiswa dalam berinteraksi dengan dunia luar kampus secara nyata yakni bisa berhadapan langsung dengan masyarakat. Mahasiswa sebagai Agent Of Change atau agen perubahan juga dapat mengembangkan pengetahuan dan wawasannya dalam menghadapi berbagai permasalahan yang ada di masyarakat Desa Sukagalih untuk melakukan pembangunan berkelanjutan yang diperlukan dalam meningkatkan peran dan pemberdayaan masyarakat dengan tujuan mencerdaskan dan mewujudkan kesejahteraan masyarakat Desa Sukagalih yang sesuai dengan lingkungan tauhid melalui berbagai bidang antara lain bidang pendidikan, bidang keagamaan, bidang kesehatan \& lingkungan, bidang ekonomi kreatif, dan bidang sosial.
\end{abstract}

Kata kunci: pengabdian masyarakat.

Mahrudin A, R Yektyastuti, Nurmalasari. 2017. Pemberdayaan masyarakat berbasis tauhid. Media Pengabdian kepada Masyarakat Qardhul Hasan 3(1): 27-38. 


\section{PENDAHULUAN}

Pengabdian masyarakat merupakan salah satu kegiatan wajib yang diikuti oleh setiap mahasiswa khususnya dari Fakultas Keguruan dan Ilmu Pendidikan. Kegiatan pengabdian masyarakat ini telah dicanangkan oleh pemerintah dalam melaksanakan tri dharma perguruan tinggi, yang kedua yaitu sebagai bentuk pengabdian mahasiswa kepada masyarakat. Setelah mahasiswa melaksanakan perkuliahan dan proses belajar mengajar selama 3 tahun yang mayoritas kegiatan tersebut dilaksanakan didalam kelas atau bangku perkuliahan, saat ini tugas mahasiswa melaksanakan pengabdian kepada masyarakat untuk mengaplikasikan semua ilmu yang telah didapatkan dalam proses pendidikan dan pengajaran.

Mahasiswa adalah agen perubahan (agent of change) yang akan melakukan perubahanperubahan nyata secara dinamis kepada masyarakat sekitar, sesuai dengan tuntutan serta kebutuhan perkembangan zaman.

Dalam program tersebutlah mahasiswa diharapkan untuk dapat ikut berperan dalam membangun desa-desa dengan pemberdayaan masyarakat pada segala bidang baik itu pendidikan, kesehatan, lingkungan serta ekonomi berbasis tauhid. Oleh karena itu, dalam kesempatan kali ini kami akan melakukan pegabdian kepada masyarakat Desa Sukagalih Kecamatan Megamendung Kabupaten Bogor. Maka dari itu kegiatan ini dapat setidaknya memberi keringanan kepada mahasiswa dalam melakukan pengabdian kepada masyarakat secara real. Setiap program yang dilaksanakan dalam kegiatan ini juga dapat memberikan manfaat terhadap masyarakat untuk memberikan solusi atas permasalahan-permasalahan yang ada di desa tersebut. Adapun beberapa permasalahan yang terjadi di Desa Sukagalih antar lain:

1. Kurangnya motivasi belajar masayarakat sekitar tentang pendidikan
2. Kurangnya pemahaman masyarakat sekitar tentang pentingnya kesehatan.

3. Kurangnya kepedulian masyarakat tentang kebersihan lingkungan sekitar.

4. Masih tingginya Angka buta huruf khususnya pada orang tua lanjut usia.

5. Kurang optimalnya kegiatan organisasi pemuda setempat.

6. Belum adanya kegiatan ekonomi kreatif berbasis masyarakat.

Berdasarkan permasalahan tersebut, maka sangat diharapkan kegiatan ini dapat menjadi penggerak bagi masyarakat dalam pengembangkan dan peningkatkan segala aktivitas, perekonomian serta pendidikan masyarakat. Tujuan pengabdian masyarakat di Desa Sukagalih yaitu:

1. Meningkatkan kualitas sarana prasarana yang menjadikan media pembelajaran di sekolah MI dan PAUD.

2. Menciptakan masyarakat yang melek huruf.

3. Menciptakan masyarakat yang semakin peduli dan termotivasi terhadap pendidikan.

4. Meningkatkan kepedulian masyarakat terhadap kebersihan dan kenyamanan lingkungan sekitar.

5. Meningkatkan pemahaman masyarakat terhadap pengetahuan ketauhidan keagamaan.

6. Menciptakan perekonomian masyarakat yang kreatif.

\section{MATERI DAN METODE}

\section{Materi}

Dasar hukum penyelenggaraan KKN FKIP, terdiri dari:

1. Undang-undang Nomor 20 tahun 2003 tentang Sistem Pendidikan Nasional;

2. Perturan Pemerintah RI Nomor 19 Tahun 2005, tentang Standar Nasional Pendidikan;

3. Undang-undang RI Nomor 19 Tahun 2005, tentang Guru dan Dosen; 
4. Peraturan Menteri Riset, Teknologi, dan Pendidikan Tinggi Nomor 44 Tahun 2015, tentang Standar Nasional Pendidikan Tinggi;

5. Keputusan Rektor Universitas Djuanda Nomor 16/2015 tentang kurikulum Program Studi Fakultas Keguruan dan Ilmu Pendiidkan Universitas Djuanda.

\section{Gambaran Umum Wilayah}

Kampung Goleah adalah salah satu kampung yang ada di Desa Sukagalih Kecamatan Megamendung Kabupaten Bogor. Desa Sukagalih yang memiliki luas wilayah 247,220 Ha dan merupakan daerah dataran tinggi dengan ketinggian dari permukaan laut $900 \mathrm{mdpl}$ dengan suhu udara $27^{\circ} \mathrm{C}-33^{\circ}$ C. Desa Sukagalih terbagi menjadi 2 (dua) kampung besar dan 4 (empat) kampung kecil yaitu : kampung Cikopo selatan, kampung Coblong, kampung Cihanjawar , Goleah, Bojongkeji, dan kampung Lemahneundeut. Desa Sukagalih terbagi 2 dusun, 4 Rukun Warga dan 20 rukun tetangga.Dengan kepadatan penduduk 0.31 per Kilometer. Penggunaan lahan oleh masyarakat Desa Sukagalih dapat dilihat pada tabel 1.

Tabel 1 Penggunaan lahan Desa Sukagalih

\begin{tabular}{clr}
\hline No & Penggunan Lahan & \multicolumn{1}{c}{ Luas (Ha) } \\
\hline 1 & Tanah Sawah & $50 \mathrm{Ha}$ \\
2 & Pemukiman & $62 \mathrm{Ha}$ \\
3 & Pekarangan & $55 \mathrm{Ha}$ \\
4 & Ladang/tanah hum & $14 \mathrm{Ha}$ \\
5 & Rawa & $3.22 \mathrm{Ha}$ \\
6 & Lapangan Olah Raga & $3.5 \mathrm{Ha}$ \\
7 & Pemakaman & $11 \mathrm{Ha}$ \\
\hline
\end{tabular}

Tabel 2 Jumlah penduduk berdasarkan umur

\begin{tabular}{llll}
\hline $\begin{array}{l}\text { Umur } \\
\text { (Tahun) }\end{array}$ & $\begin{array}{l}\text { Jumlah } \\
\text { (Jiwa) }\end{array}$ & $\begin{array}{l}\text { Umur } \\
\text { (Tahun) }\end{array}$ & $\begin{array}{l}\text { Jumlah } \\
\text { (Jiwa) }\end{array}$ \\
\hline $0-4$ & 1.030 & $40-44$ & 383 \\
$5-9$ & 1.024 & $45-49$ & 309 \\
$10-14$ & 1.044 & $50-54$ & 282 \\
$15-19$ & 949 & $55-59$ & 272 \\
$20-24$ & 875 & $60-64$ & 244 \\
$25-29$ & 525 & $65-69$ & 167 \\
$30-34$ & 587 & $>70$ & 159 \\
$35-39$ & 478 & & \\
\hline
\end{tabular}

\section{Pendidikan}

Tabel 3 Jumlah penduduk berdasarkan pendidikan

\begin{tabular}{clc}
\hline No & \multicolumn{1}{c}{ Tingkat Pendidikan } & $\begin{array}{c}\text { Jumlah } \\
\text { (Orang) }\end{array}$ \\
\hline 1 & Belum Sekolah & 1.621 \\
2 & $\begin{array}{l}\text { Tamat Sekolah Dasar } \\
\text { (SD) }\end{array}$ & 3.010 \\
3 & Tamat SLTP/Sederajat & 2.231 \\
4 & Tamat SLTA/Sederajat & 2.141 \\
5 & $\begin{array}{l}\text { Tamat } \\
\text { Akademi/Sederajat }\end{array}$ & 103 \\
6 & $\begin{array}{l}\text { Tamat Perguruan } \\
\text { Tinggi/Sederajat }\end{array}$ & 137 \\
7 & Buta Huruf & 100 \\
\hline
\end{tabular}

\section{Keadaan Sosial Ekonomi}

Keadaan ekonomi sangan erat kaitannya dengan sumber mata pencaharian penduduk dan merupakan jantung kehidupan bagi manusia, setiap orang senantiasa berusaha mendapatkan pekerjaan sesuai dengan bidang dan keahlian masing-masing, dari jumlah penduduk 8.395 jiwa yang usia pekerjaan dan pencari kerja diperkirakan sebanyak 558 jiwa. Secara umum dapat dijelaskan bahwa Desa Sukagalih bermata pencaharian Petani, buruh tani dan Pedagang, sedangkan Buruh kasar, Karyawan Swasta, Pegawai Negeri Sipil, ABRI, Petani, pertukangan dan pensiunan jumlahnya relatif kecil.

Tabel 4 Mata pencaharian penduduk Desa Sukagalih

\begin{tabular}{clr}
\hline No & \multicolumn{1}{c}{$\begin{array}{c}\text { Jenis Mata } \\
\text { Pencaharain }\end{array}$} & $\begin{array}{c}\text { Jumlah } \\
\text { (Orang) }\end{array}$ \\
\hline 1 & Buruh Swasta & 452 \\
2 & PNS & 32 \\
3 & Pengrajin & 2 \\
4 & Pedagang & 139 \\
5 & Penjahit & 7 \\
6 & Tukang Kayu & 10 \\
7 & Peternak & 32 \\
8 & Montir & 18 \\
9 & Sopir/ Pengemudi & 250 \\
10 & TNI/ Polri & 2 \\
11 & Pengusaha & 95
\end{tabular}




\section{Petani}

608

\section{Keadaan Sosial Budaya}

Masyarakat Desa Sukagalih adalah masyarakat yang religius dan agamis, terbukti dengan kegiatan peribadatannya yang masih kental dan kegiatan-kegiatan ibadah yang terus menerus dilaksanakan, maka Tabel 5 memperlihatkan klasifikasi penduduk berdasarkan agama.

Tabel 5 Jumlah penduduk berdasarkan agama

\begin{tabular}{lr}
\hline \multicolumn{1}{c}{ Agama } & Jumlah (Jiwa) \\
\hline Islam & 8295 \\
Katolik & - \\
Protestan & 11 \\
Hindu & 3 \\
Budha & - \\
\hline
\end{tabular}

\section{Kondisi Pemerintahan Desa}

Pemerintahan di Desa Sukagalih,Kecamatan Megamendung, KabupatenBogor, berlangsung dengan baik.Adanya kerja sama dan koordinasiantarpihak aparatur setempat denganmasyarakat membuat pemerintahan DesaSukagalih berjalan dengan lancar, baik ditingkat RT, RW, tokoh setempat, desamaupun kecamatan. Dalam menjalankan tugas dan fungsi dibidang Pemerintahan, Pembangunan dan kemasyarakatan, ditunjang dengan keuangan yang bersumber dari :

1. Pendapatan asli desa;

2. Alokasi Dana Desa;

3. Perimbangan keuangan Pusat dan Daerah (PDRD);

4. Bantuan Pemerintah Propinsi dan bantuan dari Pemerintah pusat melalui program PNPM Mandiri perdesaa

5. Swadaya dan partisipasi masyarakat.

\section{Pelaksanaan Kegiatan}

Kegiatan ini dilaksanakan selama 40 hari dimana pelaksanaan kegiatan KKN ini meliputi 5 divisi penting yang bersifat umum dan terdapat program-program kegiatan yang termasuk ke dalam divisi-divisi tersebut.

\section{Divisi Pendidikan}

Pendidikan adalah menjadi salah satu bagian terpenting dalam peningkatan ilmu pegetahuan di lingkungan Desa Sukagalih khususnya di Kampung Goelah. Melihat banyaknya minat dan ketertarikan pada program pendidikan ini menjadi tanggung jawab yang sangat besar untuk kami. Pada pelaksanaan program- program ini berjalan dengan lancar, dan tanpa hambatan apapun, hampir semua terlibat dalam program pendidikan ini. Dari mulai anak kecil, dewasa hingga orang tua. Karena program kami tidak hanya mewajibkan anak-anak tapi peran serta orang tua dalam pendampingan belajar seperti dalam kegiatan "Penyuluhan Pendidikan" dan adapula keikut sertaan orang tua yang belum mampu membaca dan menulis dalam program "Pemberantasan Buta Aksara”. Berikut program yang dijalankan oleh devisi pendidikan :

1. Pemberantasan Buta Aksara

Pelakasaan program pemberantasan buta aksara di Kampung Goleah Desa Sukagalih ini bermaksud untuk membantu masyarakat khususnya ibu-ibu untuk belajar membaca dan menulis, karena masih ada ibu-ibu di Kampung yang belum bisa atau belum lancar dalam membaca dan menulis. Dengan adanya program ini diharapkan ibu-ibu bisa mengenal huruf dan membaca tulisan, ada sebagian yang bisa membaca tapi tidak mampu menuliskannya kembali, ada juga yang sama sekali tidak mengenal huruf, kemudian juga ada yang mengenal tulisan dan huruf tapi tidak bisa menyambungkan kata-katanya. Adapun hambatan yang kami hadapi dalam pelaksaaann program ini yaitu sulitnya mengajak ibu-ibu untuk belajar karena kesibukannya berkebun. Oleh karena itu, kami melakukan pendekatan langsung dengan cara menemui dan mengajak masyarakat Kampung Goleah untuk ikut belajar dengan kami. Setelah program berjalan, ada peningkatan yang kami dapatkan yaitu adanya kemajuan dari peserta buta aksara ini yang telah bisa mengenal angka danhuruf, menulis, merangkai kata, dan membaca.

2. Membatu Pengajaran di MI Nurul Falah 
Pendampingan pengajaran di MI Nurul Falah, dilakukan kordinasi terlebih dahulu dengan kepala sekolah MI, setelah itu kami ditugaskan oleh setiap wali kelas untuk mengajar satu mata pelajaran yang dikuasi. Di MI Nurul Falah ini wali kelas mengajarkan setiap mata pelajaran di kelas karena tidak adanya guru pendamping atau guru khusus di sekolah ini, hal ini menyebabkan kurang maksimalnya pembelajaran dalam mata pelajaran tertentu seperti mata pelajaran Bahasa Inggris dan Olahraga. Dan hampir setiap pembelajaran guru hanya menggunkan metode, model, dan media pembelajaran yang kurang maksimal sehingga proses pembelajaran dianggap membosankan bagi siswa. Adapun hambatan yang kami hadapi dalam program ini yaitu, masih ada beberapa siswa di kelas 4, 5, dan 6 yang belum bisa atau belum lancar membaca, maka dari itu, kami melakukan pendekatan secara langsusng kepada siswa yang belum bisa membaca untuk belajar membaca di luar jam sekolah.

\section{Membantu Pengajaran di PAUD Darus Shulaha'i}

Sama halnya dengan pengajaran yang kami lakukan di MI, pengajaran di PAUD pun dilakukan dengan mengembangkan proses pembelajaran menjadi lebih menarik dan menyenangkan sehingga anak dapat lebih termotivasi untuk belajar dengan baik.

\section{Posko Pintar}

Posko pintar merupakan salah program yang dijalankan dengan tujuan untuk menambah pengetahuan dan wawasan anak dalam belajar serta membantu anak untuk dapat mengembangkan potensi yang ada dalam dirinya. Posko pintar dilakukan dengan cara memberikan pengajaran kepada siswa SD/MI di luar jam pelajaran sekolah. Adapun pembelajaran yang kami berikan yaitu belajar menggambar, Bahasa Inggris, Bahasa Arab, TIK, dan Matematika. Dengan adanya program ini pengetahuan anak menjadi semakin bertambah dan meningkat.

\section{Penyuluhan Pendidikan}

Penyuluhan pendidikan yang kami beri judul "Pentingnya Motivasi Belajar dan Peran Serta Orang Tua dalam Pendidikan
Anak" terlaksana dengan baik. Program ini bertujuan untuk memberikan pemahaman kepada orang tua dalam memotivasi anak untuk dapat meneruskan pendidikan ke jenjang yang lebih tinggi. Kurangnya motivasi dan peran serta orang tua dalam pendidikan anak di Kampung Goleah ini menjadi tantangan bagi kami, sebab tidak sedikit anak yang tidak melanjutkan sekolahnya karena minimnya dorongan dari para orang tua. Oleh karena itu, dengan adanya program ini diharapkan dapat memberi pemahaman kepada orang tua bahwa pentingnya seorang anak untuk mengembangkan potensi yang ada dalam dirinya dengan cara melanjutkan sekolah ke jenjang yang lebih tinggi.

\section{Divisi Keagamaan}

Kegiataan keagamaan merupakan kegiatan yang bertujuan untuk meningkatkan keimanan dan ketaqwaan terhadap Tuhan Yang Maha Esa. Maka dari itu program kegiatan yang dilakukan oleh divisi keagamaan adalah:

1. Ikut serta dalam pengajaran TPA

Pengajaran di TPA ini kami lakukan dengan membagi tugas sesuai dengan jadwal pengajaran yang telah kami susun. Dengan adanya pengajaran di TPA ini diharapkan dapat membantu pengajar di TPA agar lebih mudah.

2. Mengadakan Yasinan dan Dibaan untuk Bapak-bapak dan Pemuda

Yasinan dan Dzibaan (marhabaan) kegiatan ini merupakan kegiatan rutin yang dilakukan oleh warga Kampung Goleah Desa Sukagalih Kecamatan Megamendung oleh kaum bapak-bapak yang dilaksanakan di Mesjid Jami' Nurul Ikhwan setiap ba'da magrib sekitar pukul 18:30 WIB sampai selesai, adapun untuk kaum pemudanya dilaksanakan dirumah warga Kampung Goleah Desa Sukagalih setiap malam jum'at ba'da magrib, kegiatan Dibaan pemuda ini dilakukan secara bergantian setiap satu minggu sekali secara bergiliran.

3. Pengajian Majlis Ta'lim 
Pengajian mingguan ini merupakan suatu kegiatan rutinitas warga kampung Goleah yang diadakan secara bergiliran, pengajian ini terbagi dua kategori yang pertama ada pengajian kaum bapakbapak dan pemuda yang kedua pengajian ibu-ibu dan para pemudi selain dari pada itu pengajian di Kampung Goleah Desa Sukagalih terbagi empat majlis ta'lim baik pengajian bapak-bapak maupun ibuibu waktu dan tempat pengajian bapakbapa dan pemuda antara diantaranya: (1) Majlis ta'lim Nurul Ikhwan yang dilaksanakan setiap malam kamis ba'da magrib mulai pukul 18.30 sampai 20.00 WIB (2) Majlis Ta'lim Assulahai yang dilaksanakan setiap hari rabu ba'da magrib mulai pukul 18.30 sampai 20.00 WIB, (3) Majlis Ta'lim Tanwirul Qulub yang dilaksanakan setiap malam minggu ba'da magrib mulai pukul 18.30 sampai 20.00 WIB, (4) Majlis Ta'lim Al-Barokah yang dilaksanakan setiap malam senin ba'da magrib mulai pukul 18.30 sampai 20.00 WIB.

Adapun pengajian kaum ibu-ibu dan para pemudi waktu dan tempat diantaranya: (1) Majlis Ta'lim Nurul Ikhwan yang dilaksanakan setiap hari minggu pagi mulai pukul 08.00 sampai 09.00 WIB, (2) Majlis Ta'lim Assulahai yang dilaksanakan setiap hari selasa sore mulai pukul 16.00 sampai $17.00 \mathrm{WIB}$, (3) Majlis Ta'lim Tanwirul Qulub yang dilaksanakan setiap hari kamis sore mulai pukul 16.00 sampai 17.00 WIB, (4) Majlis ta'lim Al-Barokah yang dilaksanakan setiap hari kamis sore mulai pukul 16.00 sampai 17.00 WIB. Pengajian tersebut diikuti oleh warga Kampung Goleah Desa Sukagalih dengan sangat antusias. Oleh karena itu, kami menyusun program untuk ikut berpartisipasi dalam mengikuti pengajian-pengajian tersebut sesuai dengan yang telah dijadwalkan.

4. Praktek Pidato

Latihan pidato ini sangat penting bagi santri untuk dijadikan kegiatan tambahan di luar pembelajaran keagamaan lainnya terutama santri yang menjadi siswa SD/MI. Program ini bertujuan untuk meningkatkan potensi anak dalam berbicara di depan umum. Dengan begitu, anak akan terbiasa ketika ditugaskan untuk memberi ceramah atau berpidato di depan banyak orang. Kegiatan pelatihan ini dilaksanakan pada hari jum'at jam 09.30 WIBsampai jam 10.00 WIB

5. Pengadaan Al-Qur'an

Karena terbatasnya pengadaan Al-Qur'an dibeberapa Majlis Ta'lim maka kami membuat program pengadaan Al-Qur'an ditujukan kepada santri-santri yang ada di majlis ta'lim di Kampung Goleah yang bertujuan untuk memberi kemudahan dan meningkatkan motivasi santri agar dapat paham lebih cepat tentang makna dan isi Al-Qur'an.

6. Pengadaan Rak Al-Qur'an

Pengadaan rak Al-Qur'an ini diadakan untuk membantu dan mempermudah sekaligus memperindah tata ruang pengajian khususnya di majlis ta'lim yang ada di Kampung Goleah agar Al-Qur'an. Selain itu Al-Qur'an merupakan kitab suci dan panduan hidup manusia dengan kesuciaannya maka untuk penempatannya harus di simpan di tempat yang paling atas dan ditempat yang bersih serta suci.

\section{Divisi Ekonomi}

Di Kampung Goleah divisi ekonomi mengembangkan ekonomi kreatif. Ekonomi kreatif adalah ekonomi masa depan yang bertumpu pada kreasi manusia. Pengembangan ekonomi kreatif merupakan upaya menciptakan sumber daya manusia yang mampu bersaing dengan kualitas yang dapat diandalkan. Ekonomi kreatif dipedesaan difokuskan pada aktifitas ekonomi yang memberikan multiplier effect cukup besar terhadap ekonomi daerah ditinjau dari: potensi pasar, potensi ekonomi, potensi sukses, dan dampak terhadap rakyat miskin. Adapun program kegiatan yang dijalankan dalam bidang ekonomi adalah sebagai berikut: 
1. Pembuatan Bros dari Kain Perca dan Kain Bekas

Cara membuat bros dari kain perca: siapkan kain perca, jarum tangan, gunting, lem lilin, benang, pernak-pernik seperti kancing dan mutiara, pita, peniti bros. Kemudian potong kain perca memanjang kira-kira ukuran panjang dan tinggi $20 \mathrm{~cm} \times 5 \mathrm{~cm}$, selanjutnya lipat kain dan jahit mengunakan jarum tangan dan benang sampai ke ujung kemudian bentuk lingkaran dan rapikan. Lem kedua sisi bagian atas ditempel pernak pernik kancing, dibagian bawah ditempel kain flanel berbentuk lingkaran dan peniti, bros sudah jadi dan siap dikemas untuk dijual.

2. Pembuatan Celengan dari Gelas bekas Air Mineral

Cara membuat celengan dari bekas minuman aqua gelas: siapkan lem lilin, gelas bekas air mineral, kain flanel, korek api, lilin, pita, gunting. Kemudian lem kedua sisi atas gelas dan beri lubang untuk memasukkan koin, gunting kain flanel dengan ukuran panjang dan tinggi $15 \mathrm{~cm} \times 25 \mathrm{~cm}$ lem semua bagian gelas sampai tertutup dengan kain flanel, potong kain flanel berbentuk lingkaran kecil sesuai dengan ukuran koin untuk membuat mata boneka, kemudian gunting kain flanel berbentuk dua segitiga ukuran $5 \mathrm{~cm} \times 5 \mathrm{~cm} \times 5 \mathrm{~cm}$ lem potongan kain flanel tadi sesuai dengan bentuk yang diinginkan, atau hiasi celengan dengan bunga dan pita, celengan sudah jadi dan siap untuk digunakan menabung.

3. Pembuatan Celengan dari Stik Es Krim

Cara membuan tempat pensil dari stik eskrim: siapkan stik eskrim, lem lilin, korek api, pita. Kemudian lem kedua sisi stik eskrim satu persatu sampai berbentuk persegi dan lingkaran kemudian lem bagian bawah lingkaran dan rekatkan dengan stik yang berbentuk persegi, hiasi tempat pensil dengan pita, tempat pensil dari stik eskrim sudah jadi dan siap digunakan.

\section{Pembuatan Cilok Kacang Adamami.}

Kacang adamami adalah kacang yang dihasilkan oleh petani Kampung Goleah. Oleh karena itu, kami menyusun program untuk membuat cilok berbahan dasar kacang adamami. Program ini bertujuan agar masyarakat Kampung Goleah dapat memanfaatkan potensi yang ada di Kampung Goleah dengan lebih baik.

\section{Divisi Kesehatan dan Kebersihan Lingkungan}

Sumber Daya Manusia (SDM) merupakan hal penting dalam pembangunan suatu bangsa dan mutunya sangat dipengaruhi oleh tingkat pendidikan dan latihan, kesehatan dan gizi, lingkungan hidup mereka tinggal, serta kemampuan ekonomi keluarga.

Secara garis besar status kesehatan dipengaruhi oleh empat faktor yaitu lingkungan, gaya hidup perilaku, pelayanan kesehatan, dan genetik keturunan. Fakor lingkungan, yang mencakup lingkungan fisik, sosial, budaya, politilt, ekonomi, dan sebagainya. Adapun program yang dilakukan untuk menciptakan lingkungan yang bersih dan sehat di Kampung Goleah adalah:

\section{Posyandu}

Kegiatan ini bertempat di rumah ibu RT Kampung Goleah. Sasaran dari kegiatan ini adalah Anak-anak. Kendala dari kegiatan ini adalah belum adanya tempat yang permanen untuk posyandu, kurang adanya perhatian dari pemerintah, dan belum adanya pengetahuan tentang makanan 4 sehat 5 sempurna misalnya ketika posyandu selesai anak-anak dan balita di beri makanan jajanan warung bukan malah di beri makanan yang bergizi dan dan sehat sehingga solusinya adalah kami membuat bubur kacang untuk anak-anak dan balita ketika selesai posyandu. Tujuan kegiatan ini adalah untuk memberikan pengetahuan tentang makanan 4 sehat 5 sempuna dan untuk memberikan pengetahuan tentang cara hidup sehat dan bersih sejak usia dini.

2. Pembagian Polybag

Sasaran dari kegiatan ini adalah warga setempat. Kendala dari kegiatan ini 
adalah sulitnya mencari tempat/lahan untuk membuat bak sampah karena Kampung Goleah merupakan kampung padat penduduk sehingga solusinya adalah kami memilih tempat/lahan di depan persis ketika masuk ke wilayah Kampung Goleah dan menjadikan sentral pembuangan sampah untuk masyarakat. Tujuan dari kegiatan ini adalah untuk menyediakan tempat pembuangan sampah yang layak dan untuk membuat penampungan sampah.

3. Penyuluhan Kesehatan

Adanya penyuluhan kesehatan yang dilaksanakan di Kantor Desa Sukagalih dengan mengundang pemateri yang telah berpengalaman di bidangnya.

4. Penyuluhan Kesehatan Mengenai Menjaga Kesehatan Gigi

Kegiatan ini bertempat di posko mahasiswa. Sasaran dari kegiatan ini adalah anak-anak Kampung Goleah. Kendala dari kegiatan ini adalah tempat yang kurang luas karena antusias anakanak sangat tinggi tapi tempat kurang luas sehingga mengharuskan anak-anak berdesak-desakan duduknya sehingga solusinya adalah kegiatan ini difokuskan ke kelas 5 dan 6 tidak semua diikut sertakan. Tujuan dari kegiatan ini adalah untuk memberikan pengetahuan tentang cara hidup sehat khususnya mengajarkan cara menggosok gigi yang baik dan benar.

5. Pembangunan Bak Sampah

Kegiatan ini bertempat di seluruh lingkungan Kampung Goleah. Sasaran dari kegiatan ini adalah warga setempat. Kendala dari kegiatan ini adalah sulitnya mencari tempat/lahan untuk membuat bak sampah karena Kampung Goleah merupakan kampong padat penduduk sehingga solusinya adalah kami memilih tempat/lahan di depan persis ketika masuk ke wilayah Kampung Goleah dan menjadikan sentra pembuangan sampah untuk masyarakat. Tujuan dari kegiatan ini adalah untuk menyediakan tempat pembuangan sampah yang layak dan untuk membuat penampungan sampah.

\section{Pembuatan Bank Sampah}

Program bank sampah ini bertujuan untuk memanfaatkan sampah yang telah dibuang ke bak sampah untuk kemudian dikelola oleh seorang pengepul, sehingga sampah tidak terbuang secara percuma, tetapi bisa dimanfaatkan dan menjadi salah satu sumber penghasilan masyarakat Kampung Goleah.

\section{Divisi Sosial}

Berdasarkan data diatas, mayoritas pendudukan Desa Sukagalih beragama Islam. Kehidupan masyarakat yang semuanya adalah Islam dan terutama pada Kampung Goleah tercermin dari sikap dan pola hidup masyarakat yang sangat kental dengan kerukunan dan kepercayaan pada setiap orang dan ada satu yang menjadi Kampung Goleah terkenal dengan julukan "Kampung Santri" dimana masyarakat tersebut sangat menanamkan keagamaan khususnya pada pengajaran mengaji. Tidak hanya itu setiap ada pelaksanaan yang menyangkut fisik, masyarakat Kampung Goleah sangat senang dan turut membantu setiap kegiatannya baik dari laki-laki maupun perempuannya. Berikut program yang dijalakan dalam divisi sosial yaitu :

1. Peringatan Hut RI Ke-72

Peringatan HUT RI Ke-72 dimulai dengan upacara bendera, petugas upacaranya adalah mahasiswa dan pemuda setempat. Kegiatan ini bertempat di lapangan belakang MI Nurul Falah Kampung Goleah. Sasaran dari kegiatan ini adalah seluruh warga kampung Goleah. Kendala dari kegiatan ini adalah kurangnya bantuan dana dan kurang bertanggung jawab kepanitiaannya sehingga menjadikan ketidakkompakan di kegiatan ini, meskipun begitu kami harus mencari solusi menyelesaikannya yaitu dengan cara menyebar proposal ke instansi-instansi dan villa-villa dan solusi lainnya adalah kami selau melakukan pendekatan dan selalu memberikan motivasi dan arahan khususnya untuk kepanitiaan karena kepanitiaan ini kami digabung antara 
pemuda Kampung Goleah dan mahasiswa. Dengan usaha dan kerjakeras kami semua acara dapat berjalan dengan lancar dan sukses. Tujuan kegiatan ini adalah untuk mempererat tali silaturahmi antar sesama warga Kampung Goleah dan untuk meningkatkan semangat juang di antara anak-anak, pemuda dan orang tua.

2. Pembuatan Gapura HUT RI ke-72

Terlaksana mulai dari hari Senin pagi sampai Rabu malam pada jam 09.00 WIB. Kegiatan ini bertempat di Kampung Goleah. Sasaran dari kegiatan ini adalah warga setempat. Kendala dari kegiatan ini adalah sulitnya mengumpulkan pemuda dan warga kampung untuk berpartisipasi dalam kegiatan ini sehingga solusinya kami bekerja sama dengan tokoh masyarakat di kampung untuk mengajar warga bergotong royong untuk berpartisipasi dalam kegiatan ini. Tujuan kegiatan ini adalah menambah nilai estetika Kampung Goleah dan mencerminkan kepedulian dan antusias warga dalam menyambut hari besar ini.

3. Kelompok 4 Berbagi

Kegiatan ini bertempat di sekitar Kampung Goleah. Sasaran kegiatan ini adalah warga setempat yang kekurangan. Kendala dari kegiatan ini adalah kesulitan mencari sasaran karena tersorot dan ketika kami mencoba meminta data lansia yang kekurangan, datanya pun tidak ada seolah-oleh semuanya tercukupi tapi akhirnya kami sambil membagikan polibag mencari sasaran dan ternyata masih ada lansialansia yang kekurangan dari segi ekonomi. Tujuan kegiatan ini adalah memberikan keringanan terhadap ekonomi masyarakat.

4. Santunan Anak Yatim

Kegiatan ini bertempat di posko mahasiswa. Sasaran dari kegiatan ini adalah anak-anak Yatim di Kampung Goleah. Kendala dari kegiatan ini adalah kurang sabarnya mereka untuk mendapatkan apa yang kami akan berikan bahkan sampai ada yang berbicara kasar dan kurang sopan kepada kami karena takut tidak kebagian sehingga solusi yang kami lakukan adalah melakukan pendekatan dan berdiskusi karena selama ini mereka kurang kasih sayang sehingga mereka kurang mendapatkan didikan secara kurang baik dengan begitu setidaknya kami mengharapkan mereka merasakan kasih sayang dan kepedulian yang kami berikan untuk mereka. Tujuan kegiatan ini adalah mempererat persaudaraan sesame muslim saling membantu dalam beramal baik dan mengurangi beban kebutuhan hidup Anak Yatim.

\section{Sunday Outdoor Activity}

Kegiatan ini bertempat di manapun di luar ruangan sekitaran Kampung Goleah dan Desa Sukagalih. Sasaran dari kegiatan ini adalah anak-anak. Kendala dari kegiatan ini adalah banyak anak yang sebenarnya mempunyai keinginan yang banyak untuk aktif di kegiatan ini hanya saja belum ada media penyalur bakat anak-anak tersebut sehingga solusinya adalah kami menfasilitasi anak-anak untuk bisa memanfaatkan hari libur dengan mengisi kegiatan fisik yang bermanfaat contohnya seperti bermain game, berenang dan jalan-jalan. Tujuan kegiatan ini adalah merasakan kepuasan pembelajaran di alam terbuka.

\section{HASIL DAN PEMBAHASAN}

\section{Divisi Pendidikan}

Adapun hasil yang didapatkan dari bidang pendidikan yaitu sebagai berikut.

1. Tercapainya hasil belajar pada peserta buta akasara yang membantu memudahkan cara cepat menulis dan membaca, dari beberapa peserta ada kemajuan dan peningkatan, setelah berjalanya programbrantas buta aksara ini. Diharapkan para peserta ini belajar tidak hanya belajar selama ada Mahasiswasaja, tapi mereka bisa belajar kapan saja dengan orang yang mampu membaca dan menulis. Agar tidak lupa 
dengan apa yang sudah diajarkan, dan mampu mengingat kembali yang sudah di pelajari selama program berjalan.

2. Adanya penawaran dari MI setempat untuk melakukan pendampingan mengajar untuk mahasiswa, maka kami membuat program pendampingan belajar di MI tersebut dengan menugaskan kepada setiap mahasiswa untuk berpartisipasi dalam program ini. Dengan menggunakan cara pengajaran yang menarik kami mampu meningkatkan minat belajar anak di kelas. Dengan diterapkan berbagai metode, model, dan media pembelajaran yang sesuai anak mampu mengikuti pelajaran dengan lebih baik. Serta dengan diberikannya ice breaking diselasela pelmbelajaran, menjadikan suana pembelajaran lebih menarik perhatian anak.

3. Sama halnya dengan pengajaran di MI, kami melakukan pengajaran di PAUD dengan cara yang lebih menarik seperti menghias kelas, melakukan pendekatan langsung dengan anak, serta menggunakan metode yang lebih menarik sehingga minat dan motivasi anak untuk belajar semakin meningkat.

4. Dengan adanya program-program yang telah disebutkan, telah membawa dampak positif untuk peserta didik, mereka dapat mengembangkan kemampuan mereka dengan cukup baik. Misalnya, kemampuan anak dalam mengoperasikan komputer, kemampuan berbicara menggunakan bahasa Arab dan lain-lain.

5. Meningkatnya motivasi orang tua untuk menyekolahkan anak ke jenjang yang lebih tinggi serta peran serta orang tua dalam mendukung dan mengembangkan minat dan bakat anak-anaknya.

\section{Divisi Keagamaan}

Adapun yang dihasilkan dari program divisi keagamaan di Kampung Goleah adalah:

1. Terlaksanya program membaca Surat Yaasin dan Shalawat dalam melaksanakan rutinitas mingguan. Dengan program ini, adanya keistiqomahan dan bertambahnya minat masyarakat untuk berpatispasi dalam kegiatan ini.

2. Dengan adanya majlis ta'lim dan pengajian baik ibu-ibu maupun bapakbapak, maka kami membuat program untuk bisa hadir dalam pengajian tersebut sesuai dengan jadwal yang telah di buat.

3. Bertambahnya semangat serta kesadaran masyarakat untuk lebih giat dalam mencari ilmu untuk lebih mendekatkan diri kepada Allah SWT

4. Pencapaian dari program ini sangat membantu masyarakat Kampung Goleah dalam kegiatan keagamaan di kampung tersebut.

\section{Divisi Ekonomi}

Adapun barang yang dihasilkan dalam divisi ekonomi adalah sebagai berikut.

1. Terciptanya masyarakat yang semakin kreatif dalam membuat produk berupa bros, celengan, dan tempat pensil yang unik.

2. Masyarakat yang mampu mengembangkan potensi yang ada di Kampung Goleah dengan membuat cilok berbahan dasar kacang adamami.

\section{Divisi Kesehatan dan Kebersihan Lingkungan}

Adapun yang dihasilkan dari divisi kesehatan dan kebersihan lingkungan sekitar di Desa Sukagalih adalah:

1. Meningkatnya pemahaman masyarakat Kampung Goleah tentang pentingnya menjaga kebersihan lingkungan dengan tidak membuang sampah sembarangan.

2. Terciptanya tempat pembuangan sampah yang layak.

3. Adanya penyuluhan kesehatan yang dilaksanakan di Kantor Desa Sukagalih dengan mengundang pemateri yang telah berpengalaman dibidangnya. Tema dari penyuluhan ini adalah "Campak dan 
Rubela". Peserta yang mengikuti penyuluhan ini adalah dari berbagai latar belakang, seperti guru, tokoh masyarakat, orang tua, dan mahasiswa Universitas Djuanda.

\section{Divisi Sosial}

Adapun hasil yang didapatkan dalam bidang sosial adalah:

1. Terciptanya komunikasi yang lebih baik anatar sesama masyarakat, khususnya pemuda Kampung Goleah yang semakin bersatu dalam kegiatan kemasyarakatan

2. Semangat warga Kampung Goleah dalam menyambut HUT RI

3. Meningkatnya kesadaran masyarakat tentang pentingnya bersosialisasi

\section{Rencana Tindak Lanjut}

Dari beberapa rangkaian program ini ada rencana tindak lanjut, yaitu :

1. Meningkatkan Memotivasi belajar kepada para lansia karena belajar tidak mengenal batas waktu, dan usia.

2. Terciptanya karakter anak yang berakhlak mulia sesuai dengan adab yang berlalaku di Kp. Goleah dan dengan tata krama, sopan santun, dan baik.

3. Menjalankan program kegiatan-kegiatan yang sifatnya keagamaan khususnya untuk pemuda setempat yang ada di lingkungan atau wilayah Kampung Goleah.

4. Lebih menekan kebersamaan masyarakat Kampung Goleah khususnya pada saat ada kegiatan yang menyangkut kampung tersebut.

5. Memotivasi kepada pemuda setempat agar terus kompak dan tidak malu saat mengemukakan pendapat yang ada dalam pikiran mereka.

6. Terciptanya masyarakat ekonomi kreatif untuk mengembangkan potensinya dalam menghasilkan barang yang berdaya jual.

7. Pengawasan terhadap kesadaran masyarakat akan pentingnya kebersihan lingkungan melalui program bank sampah.

\section{KESIMPULAN DAN IMPLIKASI}

Adapun kesimpulan yang didapat dari kegiatan KKN di Desa Sukagallih khususnya di Kampung Goleah yaitu :

1. Rendahnya minat masyarakat buta aksara untuk belajar membaca, sehingga harus dilakukan dengan cara membujuk sebagian warga agar mau mengikuti program pemberantasan buta aksara.

2. Kurangnya pengawasan dari orang tua menyebabkan karakter kurang baik pada sebagian anak-anak Kampung Goleah, sehingga perlu adanya pendidikan karakter anak seperti kesopanan dan tata krama baik itu dalam tingkah laku maupun dalam ucapan.

3. Membuang sampah sembarangan terutama di sungai telah menjadi kebiasaan masyarakat yang sulit untuk dihilangkan, maka dari itu perlu adanya sosialisasi tentang pentingnya menjaga kebersihan lingkungan serta penyediaan bak sampah yang layak untuk selanjutnya dibentuk bank sampah.

4. Sulitnya mengajak kaum pemuda bagi yang mempunyai kesibukan untuk ikut berpartisipasi dalam kegiatan keagamaan di kampung tersebut, maka kami membuat program keagamaan yang dikhususkan untuk pemuda setempat. Dengan begitu diharapkan dapat meningkatkan pengetahuan agama kaum pemuda.

5. Saling mengingatkan dalam semua hal baik pentingnya mencari ilmu, tolong menolong, saling membantu satu sama lain dan sebagainya terutama dalam amal ma'ruf nahyi munkar.

6. Antusiasme masyarakat setempat khususnya ibu-ibu Kampung Goleah untuk mengembangkan ekonomi kreatif dalam pembuatan cilok kacang adamami dan bros dengan menggunakan kain perca. 


\section{UCAPAN TERIMAKASIH}

Dengan terselesaikannya karya ilmiah ini penulis mengucapkan terimakasih yang sedalam-dalamnya kepada:

1. Bapak/Ibu perwakilan dari BAPEDA

2. Bapak Alwansyah Sudarman, selaku Kepala Desa Sukagalih Kecamatan Megamendung Kabupaten Bogor.

3. Bapak Cecep dan Istri Ketua RW $01 \mathrm{Kp}$. Goleah Desa Sukagalih.

4. Bapak Burhanudin dan Istri Ketua RT 02/01 Kp. Goleah Desa Sukagalih

5. Bapak M. Pang Suparjan,SE.I selaku kepala sekolah MI Nurul Falah

6. Bapak Moch. Ridwan,S.Pd.I selaku pimpinan PAUD Darussulaha'i

7. KH. Dudin sebagai pimpinan Majlis Ta'lim Nurul Ikhwan
8. Ust. Hamdani sebagai pimpinan Majlis Ta'lim Tanwirul Qulub

9. Ust. Saeful Bahri sebagai pimpinan Majlis Ta'lim As-Sulahai

10. Ust. Mu'min sebagai pimpinan Majlis Ta'lim Al-Barakah

\section{DAFTAR PUSTAKA}

Dwi Hapsari dkk. Pengaruh Lingkungan Sehat, Dan Perilaku Hidup Sehat Terhadap Status Kesehatan. Pusat Penelitian dan Pengembangan Ekologi dan Status Kesehatan Jakarta. Hal. 40-41

Suryana dkk. Pengembangan Model Ekonomi Kreatif Pedesaan Melalui Value Chain Strategy Untuk Kelompok Usaha Kecil (Studi Pada Indsutri Kerajinan Di Jawa Barat). Hal. 2 